\title{
ARCHAEOLOGY
}

\section{THE ARCHITECTURAL PATRONAGE AND POLITICAL PROWESS OF HEROD THE GREAT}

\begin{abstract}
After supporting Marc Antony in the Battle of Actium (31 B.C.), King Herod, fearful of losing his power, went to Rome, apologized to Augustus and assured him that he was his biggest supporter. Augustus, giving Herod an opportunity to redeem himself, allowed him to return to Judea as King of the Jews. In an effort for Herod to express his continued commitment to Rome, he reconfigured his building styles by making cities that would depict Rome in the Levant. Herod created architecture that implemented Roman technology, designs, and styles, while co-mingling them with his existing Hellenistic style of architecture that made him forever remembered as Herod the Great.

Keywords: Agrippa, Augustus, ancient, architecture, Caesarea, Herod, Israel, Judea, near east, Sebaste.
\end{abstract}

\section{INTRODUCTION}

$\mathbf{H}$ erod the Great ruled in the Judean-Levant from 37 - 4 B.C. Some may remember him as the sadistic mass murderer of the Hasmoneans, and male infants in Bethlehem - in an attempt to kill the baby Jesus. While some scholars like Mueller dispute the latter as factual, purporting that "he is almost certainly innocent of this crime," great part of Herod's legacy. Equally congruent to Herod's sadistic legacies are his eclectic styles of architecture. During Herod's reign, he created what is known today as "Herodian Architecture." This particular style is classified as classical architecture, as it stems from the "study of physical remains of the ancient civilization of Rome." It's where Herod's ancient architectural styles and techniques from the Eastern Levant met harmoniously with Ancient Roman cosmopolitan architectural styles and techniques from the West. This research exemplifies that Herod became known as a "King of the Jews and a friend to the Romans" by showcasing his utilization of architecture, which was employed as a tool that allowed him to demonstrate his honor and patronage to Rome while simultaneously sustaining his power and creating posterity as "The Great Builder."

Focusing primarily on architectural styles and techniques that Herod apparently adopted from the Romans, possibly even duplicating some styles from his friend, Marcus Agrippa, this research provides a brief overview of general architectural similarities honed from various structures in the Western Italy that were then duplicated within the Eastern Samaria/Sebaste, and Caesarea Maritima. The primary focus is on Samaria/Sebaste and Caesarea 1 MUELLER 2008, 42.

2 DYSON/FUNARI/GRILLO 2012, 320.
Vivian A. Laughlin

Ph.D. Pre-Candidate

laughliv@andrews.edu 
Maritima because these two cities are believed to be pivotal within the ecumenical influx of Roman temple building that began in the Levant. This research will also briefly review Herod's interpersonal relationships with his court as a way of introducing his overall character, and the development of his relationship with Augustus and Agrippa. The research will continue to journey through Roman Temple-City Planning, where the integration of Roman culture within Samaria/Sebaste and Caesarea Maritima took place. This will also allow us to briefly cover the usage and implementation of Roman building materials and designs that were meant to display artistic, symbolic, and historical meaning. Then finally, we will hone specifically on Samaria/Sebaste and Caesarea Maritima as Herod's initial Roman cities where his Roman Temple building began in the Levant. This is meant to showcase how Herod utilized his architecture to display his patronage, and unity with Rome, while also exhibiting his political prowess to maintain his position of power.

\section{HEROD AND HIS COURT}

The royal court of a Hellenistic King was a network of power comprised of including, but not limited to: family; friends (philoi); state officials (bureaucrats, ambassadors, etc...); elites; domestic attendants; and any and all civil servants. ${ }^{3}$ Herod the Great followed the standard makeup of the Hellenistic court model ${ }^{4}$ down to a science. Herod learned as a young child from his father, Antipater, the Procurator of Judea, ${ }^{5}$ the importance of building relationships and its strength in obtaining and keeping power. It is because of his father that Herod understood all the dynamics within politics and how to maneuver around in it. Understanding this, Herod knew the key factor in succeeding would be to gather as many allies as possible by developing genuine friendships with those in power. He realized this was necessary in order to obtain respect from the elite, powerful circles, of which he would not ordinarily be privy.

Herod's relationship with his court has yet to be meticulously examined. However, based on the biography of Nicolaus of Damascus, Herod's Consul and Ambassador, the relationship was corrupt with intense power struggles and scheming dark attractions. ${ }^{6}$ However, recent scholars such as, Richardson and Marshak have researched the familial and friendship dynamics of Herod's court, which are quite interesting and revealing. In brief, Marc Antony protected Herod after being indicted, as he "refused to hear their complaints and dismissed them." Marc Antony and Herod had quite a devoted friendship with one another, one of mutual protection for one another, almost as brothers. Herod would repay Marc Antony with loyalty to him, until his death. Sometime later, after Marc Antony pushed the idea upon Augustus, he appointed Herod as King of Judea. ${ }^{8}$

In the midst of this, Herod met Mariamne, a Hasmonean Princess. He quickly divorced his first wife, Doris, ${ }^{9}$ banishing her and their son so that he could betroth

\footnotetext{
BIKERMAN 1938, 40-50.

KOKKINOS 1998, 86-139.

MARSHAK 2015, xxxi.

TOHER 2001, 427-247

MARSHAK 2015, 95.

RICHARDSON 1996, 128.

9 RICHARDSON 1996, 44.
}

Mariamne. Shortly thereafter, as a method to placate the Jewish population, Herod married Mariamne. ${ }^{10}$ This would solidify her Hasmonean heritage with his. Thereby, consoling the Jews to feel more comfortable having a mixed heritaged Idumean/Nabataean ruler, as opposed to the Hasmonean leadership the country had historically been known to have. ${ }^{11}$ Herod's marriage to Mariamne caused Herod to appoint Aristobulus, Mariamne's brother, as High Priest. When Aristobulus' position became official, the people rejoiced. Herod witnessed this and immediately sought to get rid of Aristobulus, as now he was seen as a threat. Later, Aristobulus was found drowned in the swimming pool that held two feet of water. ${ }^{12}$ The death of Mariamne's brother created much grief and mistrust within her marriage. Mariamne was rumored to have been unfaithful to Herod, causing Herod to kill her for treason. Herod, later, took eight more wives. ${ }^{13}$ It is important to understand this dynamic, even if in brief, as it is paramount to understanding the background, framework, and rationale for Herod's political prowess.

\section{AUGUSTUS, AGRIPPA, AND HEROD}

Augustus ruled Rome from 27-17 B.C. After the Battle of Actium in 31 B.C., Herod, who had earlier united with Marc Antony, realized this was a great mistake after Augustus won. Herod quickly switched sides to unite with Augustus. Herod, fearful of losing his power, went to Rome apologized to Augustus and assured him that he was his biggest supporter and ally. Augustus gave Herod another chance, allowing him to return as ruler of the Jews. Herod, realizing he had much in common with the Emperor, as "both had children they could not or did not rely upon,"14 may have placated this. Initially this was a tool to remain the King of the Jews, yet true friendship had begun.

Whereas Herod initiated this friendship with an agenda, once trust was established a relationship of mutual genuine admiration and respect began. Herod traveled to Rome more than once and became such a friend to Augustus that he left his children in Rome ${ }^{15}$ to obtain the great advantages of the Roman education that he had not had. ${ }^{16}$ Subsequently, his children were raised in Rome and had a noble Roman education. Herod's friendship allowed him and his children to come and go within the Emperor's home as they pleased. Herod certainly did not want to damage the dynamic of his relationship with Augustus, as it would inevitably not only ruin his own life, but also the lives of his children and grandchildren.

Augustus, like Herod, took on a multitude of building projects. Prior to Augustus, monuments in Rome took on a local political meaning and meant nothing abroad. Augustus changed this, ultimately making Roman imagery political both within Rome and abroad. ${ }^{17}$ Uniquely different than many Roman Emperors, Augustus shared his architectural fame with his architect, Agrippa. The strategic planning behind

\footnotetext{
RICHARDSON 1996, 41.

MARSHAK 2015, 111.

MARSHAK 2015, 115-116.

CURRAN 2014, 495.

RICHARDSON 1996, 263.

CURRAN 2014, 496.

RICHARDSON 1996, 3

ZANKER 2014, 83.
} 
this was for Augustus to implement a form of autonomy and acceptance for Agrippa, as Caesar had done for him. This was, perhaps, because Agrippa was not just Augustus' Architect, but also his General, son-in-law, and heir to the throne, who was entrusted with Imperial privileges equal to Augustus'. ${ }^{18}$ Because these privileges were documented in Augustus' will, ${ }^{19}$ it had become common knowledge and created strife for Marcellus, Augustus' nephew, whom the Senate and Imperial Court presumed should have had such privileges. ${ }^{20}$ Augustus, being fully aware of Marcellus' hatred, became fearful and protective of Agrippa's life and guarded it as he had his own. In an effort to protect Agrippa, Augustus sent him to the East for almost five years. ${ }^{21}$

Around 16/15 B.C., Herod visited Agrippa in Lesbos and extended a personal invitation for him to come to Judea. Upon Agrippa's arrival in 15 B.C., Herod gave him a tour of his newly constructed cities, Sebaste and Caesarea Maritima, ${ }^{22}$ to show off his architectural achievements. Josephus recounts that after Herod sailed from Italy to Asia,

"... he hastened to meet him and asked him to come to his kingdom and receive the welcome that might be expected from a host and friend. Agrippa yielded to his earnest insistence and came to Judaea. And Herod, omitting nothing that might please him, received him in his newly founded cities and, while showing him his buildings, diverted him and his friends with enjoyable food and luxury; this he did both in Sebaste and in Caesarea Maritima, at the harbor which had been constructed by him, and in the fortresses which he had built at great expense, Alexandreion, Herodeion, and Hyrcania. He also brought him to the city of Jerusalem, where all the people met Agrippa in festival attire and welcomed him with acclamations. Then Agrippa sacrificed a hecatomb to God and feasted the populace, which was not less in number than any of those in the greatest (cities)."23

After seeing the construction at Samaria/Sebaste and Caesarea Maritima, Herod's loyalty stood out to Agrippa, causing him to recognize the ambitions of Herod as a valuable asset to both him and Rome. ${ }^{24}$ One can presume an overwhelming feeling of admiration as Agrippa was touring both Samaria/Sebaste and Caesarea Maritima, as they resembled similarities to some of his own building projects in Rome. This was probably one aspect that contributed to having created their great friendship. They became such great friends that Herod's grandson was named Herod Agrippa.

\section{ROMAN TEMPLE-CITY PLANNING}

Once Herod obtained trust from Augustus, he was provided the official legal authority and affirmation to rule over both Samaria/Sebaste and Caesarea Maritima in addition to other lands. Herod, having had extensive building experience, realized the formal acquisition of the two territories presented opportunity to construct additional massive monuments that he was known for, giving him more accolades, while also presenting the opportunity to

\footnotetext{
DIO CASSIUS, Roman Hist. 54.31.

a legally binding document approved by the Roman Senate

DIO CASSIUS, Roman Hist. 54.32.

DIO CASSIUS, Roman Hist. 54.32; RICHARDSON 1996, 263.

Ant 10.5.1@12; RICHARDSON 1996, 263

Ant10.5.1@12-15.

24 HOHLFELDER 2000, 247.
}

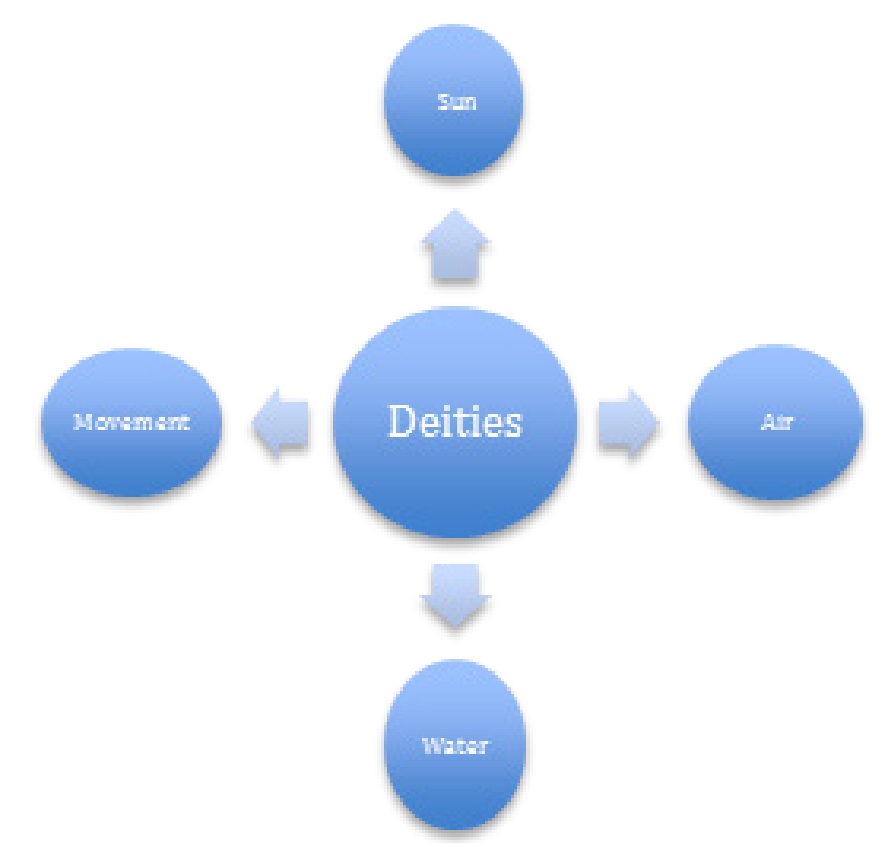

Fig.1. Chart created depicting the influence of deities the sun, air, water and all of their movement.

commemorate the new Roman Emperor, Augustus. ${ }^{25}$ Thus exhibiting his loyalty and trust, while ultimately showing off his building skills.

While Herod's legacy is known for his massive palaces, theaters, and amphitheaters, arguably even more massive were the temples constructed at Samaria/Sebaste and Caesarea Maritima. ${ }^{26}$ Herod realized that Roman religion was just as important to the Romans as the Jewish religion was to the Jews. The ancient culture of Rome viewed religion very differently than most cultures do today. Many cultures today try to separate religion and the state. However, in ancient times, religion was strongly intertwined as one with the state. ${ }^{27}$ The greatest aspect of Roman life was the love of their gods. The Romans felt "the relationship between a human and being a deity or deities finds its manifestation in the form of religion...They bound people together and gave each individual a place in society." ${ }^{28}$ Herod acknowledged the importance of this type of relationship and became very active in making Roman temples. Albeit, for Herod, everything had a strategic and political reason, as his temple buildings would not only showcase his loyalty to Rome but would also have assisted in "maintaining the balance, within [his] kingdom, between the Jewish and the Gentile populations." ${ }^{29}$ Thus, creating a more unified state and quite possibly, even more, admiration from the people towards him.

Since the official religion of Ancient Rome, was not one of monotheism, there were plenty of gods and goddesses to worship. Pliny the Elder equated the importance of deities to everything in life and nature. ${ }^{30}$ Herod embraced the 25 HOHLFELDER 2000, 241.

26 MARSHAK 2015, 209.

27 JEFFERS 1999, 89.

28 TAKACS $1995,8$.

9 NETZER 1999, 282.

${ }_{30}$ PLINY, Nat. Hist. I.I.1-2. "The world and this - whatever other men have 
deities and all they encompassed by initiating Roman temple building. While learning the importance of the deities within the universe and the role they played for the Romans, he further understood that the deities were the reason for the sun, air, water, and all their movement (figure 1). This was important because its representation needed to be exhibited in a grand way. In a further effort to display the high standards of Rome, Herod duplicated the core principles teaching of Vitruvius' architectural models (i.e., order, proportion, symmetry, décor, and economy), ${ }^{31}$ which was exhibited within every building plan. Each principle could not be possible without the other, so it had to be duplicated in totality. Vitruvius teaches the core principles of Roman architecture to be necessary, and explained the requirements for construction and their importance.

Further more, Vitruvius teaches that there is no particular hierarchy (figure 2). As previously mentioned, every principle needs the other in order to accelerate to its fullest potential. One can view it as a circle of life for ancient Roman architecture. One that allowed and required the equal necessity from each counterpart, but also showing the necessary components for one to compliment the other. While Pliny the Elder, however, expressed the importance of the deities in nature, this was not just of architecture, but

chosen to designate the sky whose vaulted roof encircles the universe, is fitly believed to be a deity, eternal, immeasurable, a being that never began to exist and never will perish. What is outside it does not concern men to explore and is not within the grasp of the human mind to guess. It is sacred, eternal, immeasurable, wholly within the whole, nay rather itself the whole, finite and resembling the infinite certain of all things and resembling the uncertain, holding in its embrace all things that are without and within, at once the work of nature and nature herself." This statement shows the importance of the deities to everything in nature and life and how it should be depicted and utilized when building.

${ }^{31}$ (Vitruvius Arch. I.1-9). "Order is the balanced adjustment of the details of the work separately, and, as to the whole, the arrangement of the proportion with a view to a symmetrical result. This is made up of Dimension, which in Greek is called posotes...Proportion implies a graceful semblance; the suitable display of details in their context. This is attained when the details of the work are of a height suitable to their breadth, of a breadth suitable to their length; in a word, when everything has a symmetrical correspondence... Symmetry also is the appropriate harmony arising out of the details of the work itself... First, in sacred buildings, either from the thickness of columns, or a triglyph, or the module; of a balista by the perforation which the Greeks call peritreton; by the space between the rowlocks in a ship which is called dipechyaia: so also the calculation of symmetries, in the case of other works, is found from the details...Décor demands the faultless ensemble of a work composed, in accordance with precedent, of approved details. It obeys convention, which in Greek is called thematismos, or custom or nature. The convention is obeyed when buildings are put up in the open and hypethral to Jupiter of the Lightning, to Heaven, the Sun, the Moon; for of these gods, both the appearance and effect we see present in the open, the world of light...Economy, however, is the suitable disposal of supplies and the site, and the thrifty and wise control of expense in the works. This will be guarded if, in the first place, the architect does not require what can only be supplied and prepared at great cost. For it is not everywhere that there is a supply of quarry sand or hewn stone, or fir or deal or marble. Different things are found in different places, the transport of them may be difficult and costly...The second stage in Economy comes, when buildings are variously disposed for the use of owners or with a view to the display of wealth or lofty enough to suit the most dignified eloquence. For manifestly houses should be arranged in one way in towns; in another way for persons whose income arises from country estates; not the same for financiers; in another way for the wealthy men of taste; for the powerful, however, by whose ideas the state is governed, there must be special adjustment to their habits. And generally, the distribution of buildings is to be adapted to the vocations of their owners." This statement is important to understanding the important parts to ancient architecture.

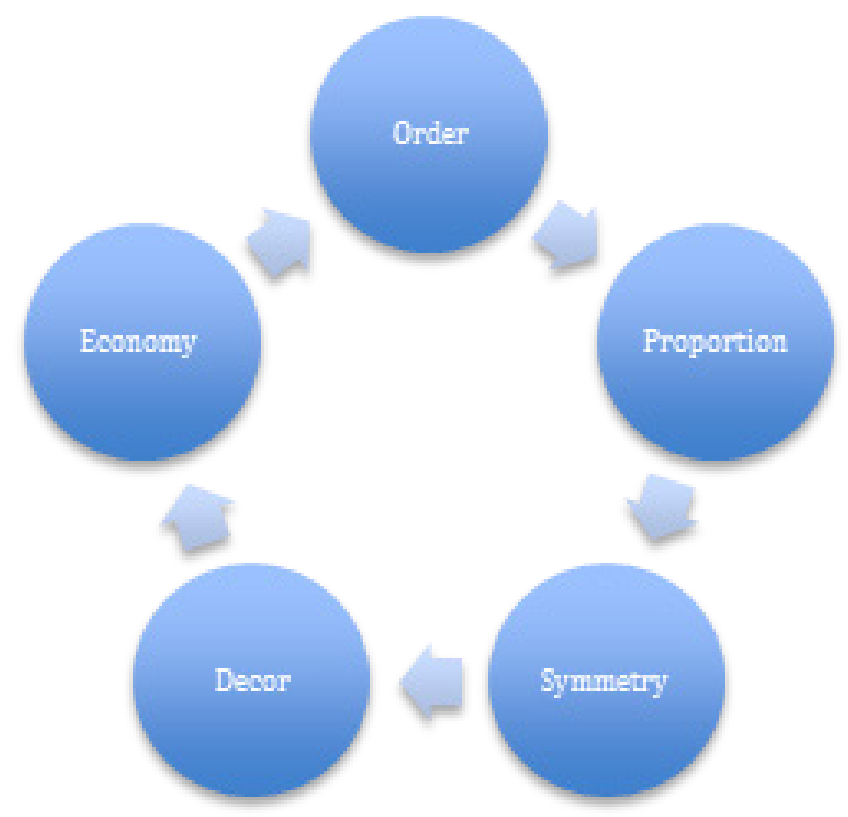

Fig. 2. Chart created depicting the lack of hierarchy and the mutual influence of Vitruvius' architecture principles.

also for life in general; and unlike Vitruvius' core principles, there is a hierarchy. The deity is the highest hierarchal need for everything, and in everything, including architecture, it should be paid tribute. Nevertheless, just as there is a mutual respect and level of importance for each core principle of Vitruvius' model, Pliny wanted to be very clear that nothing would exist without the deities, not even the sun, air, water, or its movement around us. This may be another reason why temples are built in such a grand manner. As will later be explored, each temple is set high, as if it is to reach the sun in the sky. If one was to climb to the top, the view seen would be of the water, while feeling and embracing the free flowing air, further exhibiting movement within and around the temple, making the temple and its deities the reason for it all.

In addition, implementing a city plan that included Roman temples meant the implementation of Roman culture that would inevitably be transplanted to the Levant. This would have made the general population (Jews and Gentiles) familiar with all things Roman, including their gods. With Samaria/Sebaste being located in the center of Samaria, Roman temple building would have allowed connectivity (i.e., knowledge about the gods through imagery) with the people of the region and sub-regions. Caesarea Maritima, being a harbor city, allowed connectivity to those traveling to and from other lands abroad with the purpose of trading, while simultaneously also reaching the local people of the region and sub-regions of Caesarea Maritima. This resulted in having had created an opportunity for the masses to inevitably worship Roman gods, and ultimately the Emperor. Strategically, it was political of Herod to integrate Roman temples into Samaria/Sebaste and Caesarea Maritima. The Greeks had already implemented Roman temples in their lands, which was presumably less complicated since the appearance of the Imperial Cult was essentially the same as the Greek gods that had previously been implemented during the time of Alexander the Great and later Hellenistic kings. Yet, with Rome ruling the majority of the regions in 
the Levant and consistently expanding, it became pertinent for the Levantines to learn of Roman life, accept it, and implement it into their daily practices.

\section{ROMAN BUILDING MATERIALS AND DESIGNS}

Around 37 B.C., when Herod initially began ruling Judea under Marc Antony's leadership, he slowly began implementing Roman architectural styles into his Hasmonean-Judean kingdom. This was a standard practice of implementation for the Romans, as too much sudden change would surely have exasperated the existing lovehate relationship within both his Jewish citizens, while inadvertently creating an increased hatred for the Romans. The Jews did not want to be Romanized in any way. Herod followed the Roman standard practice, which was to produce little change in the internal organization of lands they conquered. Realizing it was equally important to be tactful when introducing a new culture that was rejected by the masses, it benefited him to follow this Roman governance rule. $^{32}$

In addition, Herod's understanding that Roman religion was a political function ${ }^{33}$ may have been another political tactic, because this allowed him to delicately implement subtle Roman architectural styles by merely using Corinthian columns and Roman baths in his palaces. Herod was cunning and understood from Augustus and Agrippa that there was power in imagery. The Augustan era is known for establishing imagery by reusing ancient building practices, ultimately integrating various ancient cultural practices of its already conquered nations with the new Roman technologies. Augustus knew that imagery within the new Empire would have been useless without his many resources and allies. Ultimately, the imagery was used as a tool for juxtapositioning a new religion for Rome with a new ritual of power for the Emperor. ${ }^{34}$

Nonetheless, archaeological research on Herod's structures has helped us understand that his palaces were built according to Hellenistic styles. ${ }^{35}$ However, Herod ceased using the standard Hasmonean style of building with Doric columns, substituting them with Corinthian, which, Herod typically "reserved for the most important parts" of his palace building." 36 This may seem like a minor thing, but it was significant for two reasons: (1) the use of Corinthian columns was created and commonly used by Augustus, indicated the important levels of the structures; and, (2) the acanthus leaf, which was utilized on both the Corinthian columns and various Doric frieze fragments, ${ }^{37}$ was a plant only grown in the Mediterranean lands. This paid homage to the Emperors of the Mediterranean lands. It's usage in this decorative manner more than likely began in the early Augustan period. ${ }^{38}$ The representation of this leaf inadvertently and subtly symbolized enduring life and immortality. Thereby, also subtly symbolizing "long live the king." When Augustus and Marc Antony ruled together the

\footnotetext{
32 MILNE 1913, 1.

33 TAKACS 1995, 19.

34 ZANKER 2007, 3.

35 REGEV 2012, 183.

36 PELEG-BARKAT 2014, 145

37 PELEG-BARKAT 2014, 146

38 STRONG 1960, 120
}

acanthus leaf was utilized as a symbolic way to simultaneously display respect to both rulers. As Herod began to formally be allowed to rule additional Roman territories, this subtlety was not satisfactory and his Roman building would begin to be bolder.

When the temple building projects began, Herod wanted to build larger and grander edifices as an effort to express his continued commitment to Rome, but also to help epitomize the belief in the Roman gods. Essentially, Herod managed to restructure his building styles by making larger monuments and cities that would depict Rome in the Levant. Herod's utilization of Roman materials expanded his technology-while making his building projects stand out from previous ones. Herod, traditionally being known for his ashlar stone style monuments, began to use Roman opus caementicium (concrete) and various other Roman architectural decorations (i.e., arches, domes, Corinthian columns, etc...). While ashlar stone contributed to the contemporary building influence of the Levant and became Herod's standard style, the utilization of Roman concrete allowed Rome to influence architecture in Judea by intermingling the architectural styles and techniques of the Levant with those of the Romans. Thereby, contributing to having made Herod's building projects quite innovative for its time, as well as setting a standard of transforming the Levant in a very cosmopolitan way. Weiss characterized Herod's architectural structures as, creative, daring and innovative. ${ }^{39}$ Further expounding, "they bore a local distinctiveness but were clearly eclectic, combining traditions from the GraecoRoman East and the Western Roman Empire." ${ }^{40}$

The innovation of concrete was a technology that freed the Roman architect from the confines of rectilinear architecture, by allowing them to create innovative buildings that departed significantly from that which was previously inherited from the Etruscans and Greeks. Its innovative use started in the late Roman Republic 100-27 BC. The ingredients of concrete include a mixture of "small stones, lime mortar, sand, and pozzolana, a volcanic substance, especially plentiful in the area around the Bay of Naples." 41 The resources were utilized to create a building material that inspired the Romans to create new forms, which expressed both innovation and new technology. Ancient Roman concrete is not cut or quarried. It is cast in molds. The ancient concrete could be cast in any shape that a carpenter could build with wood. Like modern builders, the Romans erected wooden frames for their walls and ceilings and poured the concrete into them. Ancient Roman concrete, being a composite of various natural elements that became a liquid mass when mixed with water, hardened into a stronger substance that is much stronger than any of its ingredients alone. Concrete was a perfect construction material for Herod, a paranoid King who used his cities as fortresses. It would provide a much stronger foundation that would be less susceptible to damage during a war. Concrete was a great resource for him to have embarked upon and would come to be quite beneficial to him, especially with the temple building projects in both Samaria/Sebaste and Caesarea Maritima.

\footnotetext{
9 WEISS 2014, 102

WEISS 2014, 102

KLEINER 2014, 21.
} 


\section{SAMARIA/SEBASTE}

Since $9^{\text {th }}$ century BC, Samaria was the capital of Israel. One might presumably understand why King Herod would choose to make this city a priority to rebuild. Netzer states "Herod decided to rebuild and beautify the city in order to gain the loyalty of its inhabitants (and that of the population of the greater area) and named it Sebaste, the Emperor [Augustus'] Greek [name]."42 The etymological Greek origin of the name is $\Sigma \varepsilon \beta \alpha \sigma \tau \eta / \sigma \varepsilon \beta \alpha \sigma \tau$ ó $\varsigma$ (Sebaste/ Sebastos). In Hebrew, it is יסבטי (Sebaste). Pronounced: Sebaste or Sebastos, Sebaste is the feminine form-Sebastos is the masculine form. However, since the property was not a person, but part of the land/earth, the feminine form was generally used. Since it was the goal of Augustus to expand his empire, renaming the city after him may have been a way to placate and stay in the Emperor's good graces while also notifying its inhabitants and visitors that the city was now under Roman rule. The synergy of the name was so well appreciated by the masses that it was duplicated much later with a new city to have been built under the reign of Tiberius called Sebasteion Aphrodisias, known as a temple city dedicated to Aphrodite and the Judeo-Claudian Emperors. ${ }^{43}$

Excavations at Sebaste began from the inquiry and investigations of Pere Vincent O.P., of the House of St. Stephen in Jerusalem. ${ }^{44}$ The initial excavations were performed under The Harvard Expedition in 1908 and were directed by Gottlieb Schumacher. From 1909-1910 George Andrew Reisner succeeded as director. The second excavation project was a joint venture from 1931-1935 by Hebrew University in Jerusalem; the Palestine Exploration Fund; the British Academy; and the British School of Archaeology in Jerusalem that was directed by J. W. Crowfoot, Kathleen Kenyon, and E.L. Sukenik. The field reports explained a great deal about the fortified city, its accomplishments with its temple structures and its drawbacks confirming its need for rebuilt walls and the Roman innovation of aqueducts. ${ }^{45}$

Nevertheless, true to Herodian form, Sebaste was made a fortified city. Herod rebuilt the walls in order to blockade the city $^{46}$ on a "steep slope of the place as a means of strengthening it." ${ }^{\prime 7}$ This was a necessity, as the walls were "barely a kilometer across at the widest point." ${ }^{4}$ Maintaining the traditional structure of the city, Herod kept the Acropolis at the center and built the Temple of Augustus, (figure 3). Josephus accounts, "In the center of this settlement he erected a massive temple, enclosed in ground, a furlong and a half in length, consecrated to Caesar; while he named the town itself Sebaste. The inhabitants were given a privileged constitution." ${ }^{49}$ Netzer's archaeological research reveals, "Herod's major efforts here were invested in the construction of a pagan temple and the fortifications into which its precinct was integrated." ${ }^{50}$

The temple was very large consisting of "approximately

\footnotetext{
${ }_{42}$ NETZER 2009, 81 .

${ }_{43}$ SMITH 1987, 88.

${ }^{44}$ CROWFOOT/KENYON/SUKENIK 1942, XV.

${ }_{45}$ CROWFOOT/KENYON/SUKENIK 1942, 1.

46.JW1.10.10@64.

47 Ant 10.5@297.

48 CROWFOOT/KENYON/SUKENIK 1942, 1.

49 JW1.10.10@403.

50 NETZER 2009, 82.
}

115 feet long and 80 feet wide with a portico 23 feet deep in front. In front was a large forecourt, which measured about 20 feet by 170 feet and was accessed by a flight of twentyfour steps, divided into two equal levels. The temple stood 1450 feet above sea level and was erected on a podium 14 feet above the forecourt." ${ }^{51} 52$ This was a massive structure. The temple to Augustus at Sebaste, like the temple Herod built in Jerusalem, had similar resemblances, as they addressed similar problems. Because the amount of space at each location did not consist of enough room to build as massive a structure as Herod was accustomed to (or the standard practice of Roman temple building) he built both temples on raised platforms. ${ }^{53}$ Given the probability of a war, and because stone was typically used in the East when building temples, the temple was built with concrete as the primary foundation. ${ }^{54}$ The temple at Sebaste also had a "hexastyle Corinthian façade, and the cella [partitioned room] was divided into a broad nave and two narrow side aisles." ${ }_{55}$

Nevertheless, while Rocca indicates that visually the temple at Sebaste had similar external characteristics as the Temple of Venus in Rome, ${ }^{56}$ Marshak's tripartite cella description suggests similarities to the interior of the Jupiter Optimus Maximus, also known as the Capitoline Triad Temple, located at the Capitoline Hill in Rome. The tripartite cella similarity may not be happenstance. The Temple of Jupiter Optimus Maximus was erected in 509 B.C. and was destroyed four times in history. The second time it was destroyed, it was rebuilt and repaired during Augustus' reign by Agrippa. The Temple of Jupiter Optimus Maximus is considered to be the grandest epitome of Roman temples, as it is dedicated to the Capitoline Triad: Jupiter (Zeus), Juno (Hera), and Minerva (Athena). Jupiter was the King of the gods; Juno was his sister/wife, Queen of the gods; and

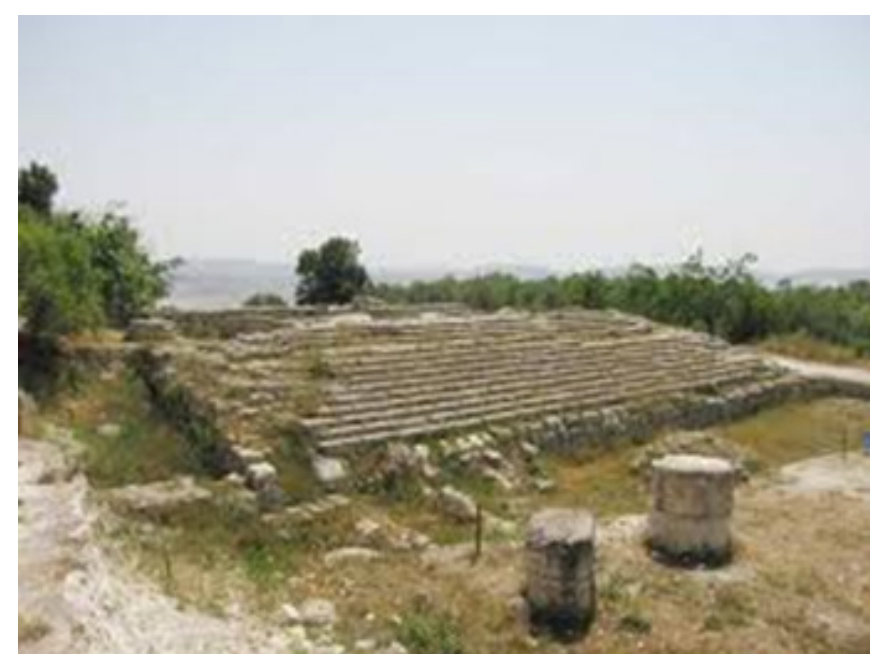

Fig. 3. Temple to Augustus at Samaria/Sebaste.

MARSHAK 2015, 209.

52 REISNER/FISHER/LYON 1924, 177. This is the original field report that Marshak would have presumably gotten the measurements from. Please note: Excavation field reports measurements are always in meters, as opposed to feet.

CROWFOOT/KENYON/SUKENIK 1942, 127.

NELSON 2015, 79.

MARSHAK 2015, 209

ROCCA 2008, 317. 
Minerva was their daughter, the god of wisdom. Jupiter's cella was always in the center, with two cellas on opposite sides for Juno and Minerva. The Jupiter Optimus Maximus Temple is not to be confused with singular cella temples dedicated solely to Jupiter. The Jupiter Optimus Maximus Temple is dedicated to all three deities simultaneously.

According to legend, Jupiter approved and designated Augustus as an equivalent to the gods. Suetonius describes an event that explains how Jupiter blessed Augustus and proclaimed him the Emperor. ${ }^{57}$ Perhaps the internal architectural building style similarities were based on these dreams. Because of the symbolic aspects of Augustus' deification into his position as Emperor (having been appointed the future Emperor by Jupiter, the King of the Roman deities), Herod may have intermingled the history of these dreams within his architectural plans. Thereby, recreating the cosmological predictions of Quintus Catulus' dreams - wherein Jupiter proclaimed Augustus as the future ruler of Rome was captured in an artistic form of hidden imagery within his architecture. This may have been a method to continuously and artistically convey that the Augustus was, in fact, a true god appointed and received as such by the Supreme Roman god (at that time), Jupiter. But, also as a way of stimulating a reason for the masses to simultaneously worship Augustus while worshipping Jupiter Optimus Maximus. Thus, making the temple at Sebaste symbolic to Augustus. If this were the case, one might understand how Augustus and Agrippa would embrace Herod and make him as one of the royal family, especially after his display of such betrayal during the Battle of Actium - which he would have ordinarily been subject to death, by cause of treason.

Aside from the tripartite cella for each deity, there are also additional structural similarities of the temple at Sebaste that are very similar to that of the Temple of Jupiter Optimus Maximus. They both were: built on a high podium; contained Corinthian columns with a façade orientation; and had a large front porch. While these similarities are important, the most interesting architectural observation about the Temple to Augustus at Sebaste is that while its massive structure of $35 \times 24$ meters stood out - being on the highest part of the hill, ${ }^{58}$ it was built within a "cultic precinct or forecourt and did not stand alone." ${ }^{59}$ In the excavation reports of Crowfoot/Kenyon/Sukenik 1942, the remains of a temple dedicated to Kore, the Ancient Cult of Persephone,

\footnotetext{
SUETONIUS 2.8. "After Quintus Catulus had dedicated the Capitol, he had dreams on two nights in succession: first, that Jupiter Optimus Maximus called aside one of a number of boys of good family, who were playing around his altar, and put in the fold of his toga an image of Roma, which he was carrying in his hand; the next night he dreamt that he saw this same boy in the lap of Jupiter of the Capitol and that when he had ordered that he be removed, the god warned him to desist, declaring that the boy was being reared to be the saviour of his country. When Catulus next day met Augustus, whom he had never seen before, he looked at him in great surprise and said that he was very like the boy of whom he had dreamed... As Marcus Cicero was attending Gaius Caesar to the Capitol, he happened to tell his friends a dream of the night before; that a boy of noble countenance was let down from heaven on a golden chain and, standing at the door of the temple, was given a whip by Jupiter. Just then suddenly catching sight of Augustus, who was still unknown to the greater number of those present and had been brought to the ceremony by his uncle Caesar, he declared that he was the very one whose form had appeared to him in his dream."

58 NEGEV 1976; CROWFOOT/KENYON/SUKENIK 1942, 126.

59 ROCCA 2008, 317.
}

which superseded the Cult of Isis and Serapis in the Roman era, was discovered in area T. ${ }^{60}$ The remains of the temple to Isis was also uncovered, which indicated that it was built partly out of the ruins of the old Hellenistic temple once dedicated to Kore. ${ }^{61}$

This was interesting because while the Isis and Serapis cult maintained its existence there it was not to pay tribute to anything pertaining to Egypt. The Isis and Serapis cult, while derived out of the Hellenistic-Egyptian Ptolemaic Sarapis cult, had begun to be a Romanized cult. The Sarapis cult was originally occupied with both Greek and Egyptian gods. The supreme gods were Egyptian, Osiris and Apis, simultaneously. However, this supreme god comprised of Egyptian deities carried a very Greek appearance. When the Serapis Cult was imported and implemented by Augustus, the supreme god combination of Osiris and Apis were replaced with a singular god, Isis. Isis became the supreme god reigning over all the gods Greek, Egyptian, and Roman alike. Augustus utilized the Serapis cult as a method for his political prowess by making it a political function and more significantly attaching it to the House of Augustus. ${ }^{62}$ Doing this reflected to the Roman world that the divine realm was very much a part of the Imperial power and so was the authority assigned to Augustus. Thus making the Emperor a walking god. Paramount to anything else, with the incorporation of the plethora of gods into Serapis, this also meant that by worshipping any other god whether it was Greek, Roman, or Egyptian, one inadvertently worshiped Serapis. Which also meant one automatically, and perhaps inadvertently, also worshiped the Roman Emperor simultaneously.

\section{CAESAREA MARITIMA}

In 1960 Edwin Link formed a team of professional divers under the direction of $C$ harles $T$. Fritsch and Immanuel Ben-Dor ${ }^{63}$ underwater exploration of the submerged sections of Sebastos and Caesarea Maritima took place. In 1979 the combined forces of the Caesarea Maritima Ancient Harbor Project (CAHEP) was conducted by Avner Raban and Elisha Linder, Center for Maritime Studies, and the University of Colorado with Robert L. Hohlfelder serving as co-director ${ }^{64}$ explored Caesarea Maritima, and because of its closeness in proximity, inadvertently also explored Sebastos, which was adjoined to Caesarea Maritima and is not to be confused with Samaria/Sebaste. Hohlfelder, et. al, acknowledges that "Sebastos, itself, had technological features found nowhere else in the world. At the time of its completion it was not only the largest Levantine harbor but also one that showed a maritime engineering sophistication that can only be called modern." 65 Josephus said that Sebastos contained civic structures that would be common to any major Roman city, and that it was most impressive architecturally, having had to be carved from an uncompromising coastline that was

\footnotetext{
60 MAGNESS 2001, 159; CROWFOOT/KENYON/SUKENIK 1942 62-66.

${ }_{61}$ CROWFOOT/KENYON/SUKENIK 1942, 66-67.

62 TAKACS 1995,19

3 HOHLFELDER/OLESON/RABAN/VANN 1983, 134

4 HOHLEFELDER 1988, 1-12.

5 HOHLFELDER/OLESON/RABAN/VANN 1983, 133.
} 
void of a cape or bay. ${ }^{66}$ Since the explorations of the Scholars, many have been intrigued and fascinated with the area of land, because it, too, was built with the sole purpose of expanding the Roman Empire and the Imperial Cult in the East.

Herod, having had the building experience with Samaria/Sebaste, would set his sights to build Caesarea Maritima in a grander manner. Caesarea Maritima would become a very important building project because it was "on a section of the coastline that had recently belonged to Cleopatra [VII] before its repatriation following the Rhodes settlement." 67 It was quite ironic for Herod to have had acquired a piece of land once belonging to Egypt's Queen. Especially since this new acquisition was right after the Battle of Actium, making Egypt a newly acquired province under Rome. To compound insult with injury, Herod made Caesarea Maritima, a trading harbor city, and one that would compete with the harbor of Alexandria. This sardonic message must have carried a strong sense of patronage to Augustus that appeased him. It allowed Herod to display his loyalty to Augustus by dishonoring the Queen who had come between Augustus and Marc Antony, while simultaneously allowing Augustus to fully proclaim the land Marc Antony had love stricken and foolishly gave away. Not to mention the prospective amount of income to be generated from the trans-Atlantic trading industry. Acquiring this land had endless possibilities of prosperity for both Herod and Rome.

This was the harbor city that historically had the name Stratos Tower, founded by the King of Sidon. Herod, wanting to rid his newly acquired territory of its history chose to rename the land Caesarea Maritima. Doing so would ratify his love for both old Rome, under Augustus' mentor, Caesar, while simultaneously showing his patronage to the new Rome under Augustus. Caesarea Maritima was considered to be the "most beautiful both in material and construction." 68 In addition to this being a great port city, it would become the "administrative center of Roman police control and tax collection in its district, two important functions of cities in eastern provinces." ${ }^{69}$ Like at Samaria/Sebaste, Roman materials and design styles were utilized during its construction. A unique thing about this city is that Herod built it from scratch, providing an opportunity for him to create his own canvas for his artistic work. Herod put Roman concrete in boats and then sunk the boats until it was high enough for him to build a harbor on top. The entire city was made of concrete. This made the city of Caesarea Maritima withstand the probable hardships of war, and nature by having a strong foundation created right from within the body of water. Making Herod, one to have conquered nature.

As an effort to mimic the styles of Roman port cities, Herod made the harbor opening "comparable to Ostia and other great Imperial harbors such as Leptis Magna."70 Another unique structure at Caesarea Maritima, according to Roman inscriptions, ${ }^{71}$ are the aqueducts. Previous scholarship ${ }^{72}$

\footnotetext{
66 JW1.10.10@408-414; Ant 10.5@331-341.

67 HOHLFELDER 2000, 242.

68 Ant 10.5. 340

69 BEEBE 1983, 196.

70 CASSON 1971, 368.

1 SCHÜRER 1886; VILNAY 1928; HAMBURGER 1959

72 REIFENBERG 1951, 26.
}

dispute that Herod actually built aqueducts, claiming instead that Hadrian built them much later. However, more recent scholarship has demonstrated that Hadrian only made repairs to the original aqueducts built by Herod. ${ }^{73}$ Because water was not good at this port city, it was very necessary to build plumbing. Aqueducts were another innovative Roman design that Herod implemented in the Levant. The utilization of aqueducts made this Eastern province far more cosmopolitan than any of its neighboring cities in the Levant, with the exception of Samaria/Sebaste that also had aqueducts. ${ }^{74}$

Architecturally, Herod accomplished much at Caesarea Maritima. Unfortunately, much of it is not examined within the scope of this research. However, one of the great architectural structures that will be examined is the temple dedicated to both Augustus and Roma (figure 4). Josephus notes that the temple was on a hill. ${ }^{75}$ However, this temple was built on a raised podium to give the appearance of it being on a hill as a measure to signify both its massive size, and its greatness within the cosmological realm. This was to create the illusion of "holiness," as it was located on a hill, and appeared as if it was high in the sky, like the gods. The temple is said to have been so large that it had Corinthian orders that reached nearly twenty-two meters high. Magness describes the Temple as having been "...constructed in an Italic rather than a Hellenistic style. The Italic features include the placement of the temple on a tall, raised podium that was accessed by steps only on the west (with the porch facing the harbor), creating an axiality and a frontality that differed from Greek temples."76 MacDonald further states that such "details are signs of the Empire, like the traditional Corinthian colonnade, which, with its slender shafts rising from bases of layered stone discs to wreathed capitals above, epitomized the grand formal manner of the age."77

Much of the above sounds very familiar to the Roman temple at Samaria/Sebaste. However, Holem points out the uniqueness of this temple is that Herod managed to capture the essence of a Roman structure while duplicating many characteristics from Jerusalem's Temple Mount, which he was building simultaneously while constructing Caesarea Maritima. "Apparently, the two building projects, pagan and Jewish, proceeded in tandem in the two cities. With a hint of irony, and drawing attention to the parallelism of Herod's projects in Jerusalem and Caesarea Maritima." 78 Arguably, the visible Roman and Hellenistic styles may have been Herod's way of (1) keeping his own identity while utilizing new Roman styles and technologies; and (2) creating images with some similarities for the Jews as an effort to provide a visual comfort level for them. Thereby, leaving his mark in the architectural world by creating his own architectural style, while again, paying the utmost respect to Rome.

Notably, Caesarea Maritima was more than likely intended to be duplicative of Rome's Forum, as it was also meant to be the primary location for the local Roman government in the Levant. It became a tax center and a place that focused primarily on the personal and public growth of

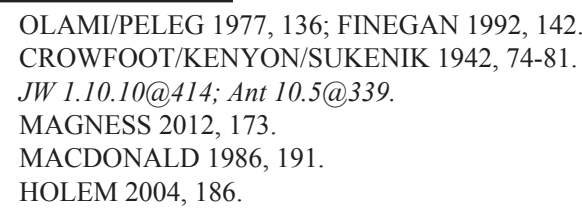




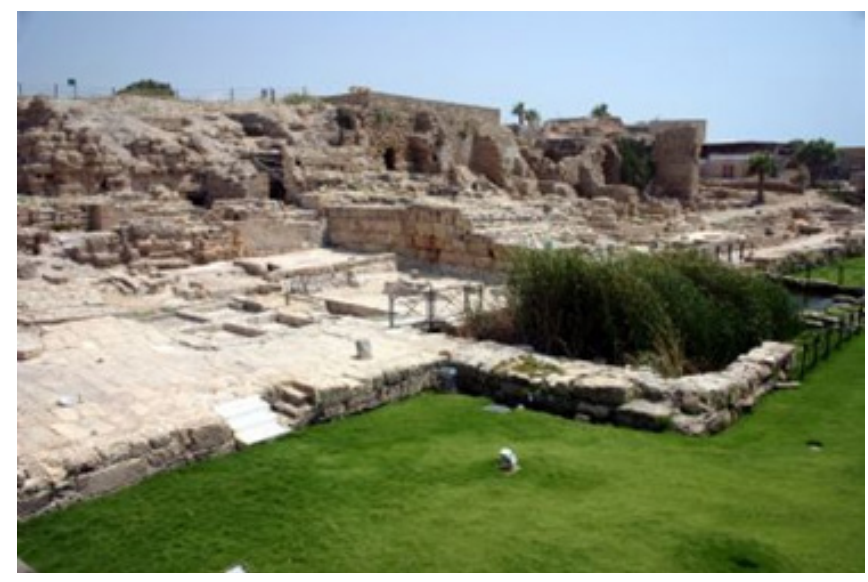

Fig. 4. Temple to Augustus and Roma at Caesarea.

Augustus as Emperor. Therefore, the symbolic similarity of the Temple to Augustus and Roma in Caesarea Maritima to that of Mars Ultor located in Rome's Forum was elevated. One might question how this is possible when, as previously mentioned, there are notable architectural similarities of the temple at Caesarea Maritima to that of the temple at Samaria/ Sebaste. Nonetheless, in this particular instance, particular attention should be honed on the artistic, symbolic, and historical similarities of the Temple to Augustus and Roma that are similar to that of Mars Ultor. Notwithstanding, the temple of Mars Ultor was architecturally influenced by the Temple of Jupiter Optimus Maximus, as the Temple to Augustus at Sebaste, and it was said to be Augustus' "most ambitious architectural undertaking." 79 Thereby making it a great reason to emulate its style. However, focusing on the artistic, symbolic, and historical meanings of this structure assists with understanding the historical theory. Understanding the historical theory helps one to see there is a recursive relationship between theory and practice, which allows a cause and an effect, and even permits an event to become labeled as an action that has expressed some serious thought by its agent, in this case the agent is Herod. ${ }^{80}$ The purpose of which was to create monumental forms including histories of order, proportion, symmetry, décor, and economy.

Mars Ultor was initially built as a result of defeating Brutus and Cassius. Perhaps Herod duplicated this temple at Caesarea Maritima, to send a further well-thought out message - one that would be a reminder of Augustus' military youth (of defeating Brutus and Cassius) while simultaneously honoring and displaying his defeat of Marc Antony and Cleopatra. Additionally, while it took several decades to complete the construction of the Temple of Mars Ultor, the premise behind it was Augustus' expansion of the Imperial Cult, which was also a major priority of Herod. Last but not least, the Temple of Mars Ultor permeated Roman religious reform. ${ }^{81}$ Since "founding a city in the ancient world was considered a sacred act," 82 building a Temple to Augustus and Roma in a newly built city by Herod would have caused

\footnotetext{
79 STAMPER 2005, 130
}

80 (COLLINGWOOD 1939, 127-128; HODDER/HUTSON 2003, 146; GIDDENS 1984, 162-227; BOURDIEU 1977, 72-87. While these are sociological related, the methodology therein is applicable and practical to understanding archaeology. These methods are being applied more within archaeology.

81 STAMPER 2005, 130

82 LEVINE 1975, 15. the temple to seemingly be perceived as more sacred-while possibly also illuminating Augustus as a god and helping him to be perceived as a holy man. At this time, Herod was still not well received or liked by the general population. Building a Roman temple may have also been a motivating factor to make the gentiles living in this vicinity feel as though they had a place within a predominantly Jewish region of Rome. Accordingly, also having had created a situation that would have made some people begin to like Herod would have been a win-win situation. Thereby, assisting with the autonomy and harmony of the population at Caesarea Maritima.

\section{CONCLUSION}

History exemplifies that Herod was a complex man, one with great paranoia who partook of barbarian acts to protect his throne. Yet he was also a man who was loyal to his trusted friends. Herod's reputation as a great builder is congruent with his reputation as a sadistic murderer. During a time, where cities were created from conglomerations of structures, Herod took risks and created a unique building style at Caesarea Maritima, one that introduced the realm of creating cities first, and then building massive structures within them. Thus, making the cities themselves equally monumental to its structures therein. It was important for Herod to partake of city building because he knew even if his structures wouldn't survive after him, a city probably would. This is pivotal to him being remembered long after his death. It is further believed that within the rebuilding of Samaria/Sebaste and the building of Caesarea Maritima that Herod's reputation may have begun to change for the better. ${ }^{83}$ Perhaps it was his interest in obtaining favor by the Emperor, but ultimately it served to gain the gentile populations favor as well.

One might question, why Herod, a Jew, would be inclined to risk his already terrible reputation with the Jews to build temples to non-Jewish gods? While Herod was a practicing Jew ${ }^{84}$ the Hellenistic culture at the time perpetuated considerable intermingling. In $1^{\text {st }}$ century B.C. Jerusalem, it was common for Jewish elites to embrace all people from all walks of life. Doing so meant they had to have interfaith dialogue for which they needed to speak Greek, Latin, and Aramaic/Hebrew. However, this interfaith dialogue eventually led to implementing and merging various cultural practices into the Jewish ones like dressing in Hellenistic styled clothing, obtaining Roman citizenship, and giving up the standard Jewish diet. Jeffers indicates that the average Jewish dinner would have been served in the same type of banquet style that may have been seen in Athens or Rome. ${ }^{85}$ Therefore, while the overall concept was that the general Jewish population rejected Romanization. The elite Jewish population had begun to subliminally implement various aspects of Romanization into their personal lives.

Arguably, Herod's interfaith experiences may have become influential within his cultural practices, allowing his personal interfaith experience to intertwine within his building projects. To this end, it served to his advantage, as

\footnotetext{
33 MCCANE 2008, 726

84 PEROWNE 2015

85 JEFFERS 1999, 14.
} 
it helped to burgeon the emergence of a Herodian building phenomenon. As previously mentioned, the temples at both Samaria/Sebaste and Caesarea Maritima created an influx of temple building that sparked Herod to build the Temple to Ba'al Shamim at Si'a and memorials to Abraham in Idumea (i.e., Haram al Khalil, and Mamre's Haram Ramet al-Khalil). While building a temple to Abraham would have been completely against Jewish tradition, Herod built memorials instead to commemorate Abraham and his descendants. "The Idumean location of both suggests Herod aimed to incorporate patriarchal traditions-common to both Edomites and Israelites - and to appeal to Judeans and Idumeans, who like his own family, had embraced Judaism." ${ }^{86}$ These memorials were perhaps built because Herod presumably experienced compunctions about supporting other deities outside the Jewish faith, ${ }^{87}$ and may have attempted to redeem himself within his Jewish religion by doing this. Nevertheless, Herod learned to balance the competing needs of Judaism and the needs of Rome, ${ }^{88}$ while also having had created a royalty line for his Jewish family directly from the Roman Emperor.

Samaria/Sebaste and Caesarea Maritima, having shared the commonality of being cosmopolitan cities with temples dedicated to Augustus, assisted greatly with expanding the Roman Imperial Cult in the Eastern provinces. Herod made certain to build a temple to the Emperor Augustus in these cities as a way of fostering deeper loyalty. This inadvertently ensured the worshipping of not just the Roman gods, but also the Emperor, the latter being of high priority to Augustus. Monuments that were built to mimic the glory of Rome, simultaneously created an opportunity to further expand the Roman Imperial Cult. "Recognizing [that] old political, religious and cultural patterns were passing away and that a new synthesis-a first-century Mediterranean version of globalization-was on the way" ${ }^{89}$, Herod built Roman temples to begin the process of implementing a cross-cultural understanding of Roman life and gods foreign to the people in the vicinity. The exhibition of these temples was not just for the sake of architecture but was "cosmopolitan and ecumenical. Within a highly urban context, it was framed around personal and institutional ritual," ${ }^{90}$ as a compulsive attraction came with the spread of Romanization that motivated participation within the empire. ${ }^{91}$ This was the purpose of the architecture.

Herod contributed to this compulsive desire by creating imagery with his monumental architectural structures, while also contributing to the implementation of a new construction that introduced a new epistemological system, ${ }^{92}$ and a new religion. The intermingling of Roman architectural styles with those of his own contributed to an altered topography in the Levant, which we call Herodian Architecture. While simultaneously appeasing the Emperor (i.e., showing that he was dedicated to Rome), Samaria/ Sebaste and Caesarea Maritima became two cities in the

\footnotetext{
${ }_{86}$ RICHARDSON 2004, 279.

${ }_{87}$ RICHARDSON 1996, 67.

88 RICHARDSON 1996, 18.

89 MCCANE 2008, 727.

90 YEGUL 2012, 37.

91 MACMULLEN 1981, 134

92 WALLACE-HADRILL 2005, 81
}

Levant that were free of Jewish nationalism, and with cultures that accepted Roman dictatorship. The strategic planning necessary for such a feat must have taken quite some time. A number of necessary resources and supplies alone make it "highly probable that perhaps Augustus and Herod discussed Roman hegemony in Syria and Palestine." ${ }^{\text {93 }}$ This conversation was quite probable given that "Herod's construction of Sebastos on the site of ancient Samaria might have fulfilled that purpose since Jewish and Samaritan hatred of each other would have denied Sebastos any symbolic value in uniting Jews against Roman rule, but it would not satisfy Rome's need for a harbor." 94 Herod also understood that while appeasing Augustus' ego, he also needed to appease him financially. Making Caesarea a port city would bring in finances, while also making it a complete Roman governmental agency within the client state. It was pivotally understood that by building Roman temples he provided a sacred place to worship the Roman Emperor. Indeed, also a place for sacrifices and appealingly pay the gods, funds of which would ultimately go to the Roman Emperor. The embodiment of it all would have created a winwin situation for both Augustus and Herod. Paramount for Herod, it was equally important to stay in good graces with the Emperor, and stay in power, not just for him but also his heirs.

Herod's architectural styles duplicated that of Agrippa's, but further complimented the royal family. As mentioned above, much of Rome's political designs were intended to having meaning locally. Herod broadened those horizons by importing the architectural styles of Rome, and the Roman history reflected within these architectural styles-by allowing his structures to tell artistic, symbolic, and historical stories. The implementation of Roman innovative technologies, styles, and designs allowed Herod to experiment with commingling the Hellenistic style of his culture for which he was known with something new. While, the utilization of Roman technology assisted greatly within the overall Roman landscape allowed Herod to architecturally capture the deities within the natural elements (which they controlled), it also allowed him to show the beauty and symbolic meaning of the deities, while also completing his goal of bringing Rome to the Levant.

Moreover, Herod may have been the builder that assisted with the expansion of the Imperial Cult east of the Mediterranean. Thereby, having had contributed to it being the fastest growing and the most widespread of all cults. ${ }^{95}$ Previously, the Imperial Cult had been instituted sporadically for special occasions. But as it began to expand under Augustus, it appeared everywhere. This movement, conceivably, made it more of a priority for Herod to show Augustus his loyalty by promoting it as well. Herod began to implement the Imperial Cult into his building projects and made them grander by utilizing Roman technology, which contributed to his creating a far more Roman appearance than his Greek counterparts.

Herod understood these acts would benefit him with remaining in Augustus' good graces; and would also serve

\footnotetext{
3 BEEBE 1983, 202.

BEEBE 1983, 206.

5 ZANKER 2007, 297.
} 
himself, as he, true to Roman architectural standards, would have wanted to go down into history as a great builder. Herod was a man that allowed his paranoia and his drive for achievement to play a strong role in his political prowess, ultimately exhibiting his savoir-faire (knowing how to do) both in ruling and controlling the population over which he ruled, as well as creating a pathway for the population to begin to accept Romanization. Finally, by combining Eastern and Roman architecture of the West, Herod was ahead of his time. Perhaps this may have been the fire that sparked the use of these artistic practices within future Roman architectural standards. Such practices were befitting of "the Great King" that he was. In the words of Josephus, Herod was "a man who was cruel to all alike and one who easily gave in to anger and was contemptuous of justice. And yet he was as greatly favored by fortune as any man has ever been in that from being a commoner he was made king...."96

\section{REFERENCES}

\section{BEEBE 1983}

Beebe, H. K., Caesarea Maritima Maritima: Its Strategic and Political Significance to Rome, Journal of Near Eastern Studies 42, 195-207.

BIKERMAN 1938

Bikerman, E., Institutions des Seléucides (Paris: Geuthner).

BOURDIEU 1977

Bourdieu, P., Outline of a Theory in Practice (New York:

CASSON 1971 Cambridge University Press).

Casson, L., Ships and Seamanship in the Ancient World (Princeton: Princeton University).

COLLINGWOOD 1939

Collingwood, R. G., An Autobiography (Oxford: Oxford University Press).

\section{CROWFOOT/KENYON/SUKENIK 1942}

Crowfoot, J.W./Kenyon, K.M./Sukenik, E.L., The Buildings at Samaria (London: Palestine Exploration Fund).

\section{CURRAN 2014}

Curran, J., Philorhomaioi: The Herods between Rome and Jerusalem, Journal for the Study of Judaism 45, 493-522.

DYSON/FUNARI/GRILLO 2012, 320-5

Dyson, S./Funari, P.P.A./Grillo, J.G.C., Classical Archaeology in vol. 1. Silberman, N.A./Bauer, A.A./Holtorf, C/DiazAndreu, M./Waterton, E. (eds.), The Oxford Companion to Archaeology Second Edition (New York: Oxford University Press).

FINEGAN 1992

Finegan, J., The Archeology of the New Testament: the Life of Jesus and the Beginning of the Early Church (Princeton: Princeton University Press).

GIDDENS 1984

Giddens, A., The Constitution of Society: Outline of Theory of Structuration (Berkeley: University of California Press).

HAMBURGER 1959

Hamburger, H., A New Inscription from the Caesarea Maritima Aqueduct, Israel Exploration Journal 9, 188-90.

HODDER/HUDSON 2003

Hodder, I./Hutson, S., Reading the Past: Current Approaches to Interpretation in Archaeology (New York: Cambridge University Press).

HOHLFELDER 2000

Hohlfelder, R. L., Beyond Coincidence? Marcus Agrippa and King Herod's Harbor, Journal of Near Eastern Studies 59,

\footnotetext{
96.Ant 10.5.1.1@191-2.
}

241-53.

\section{HOHLFELDER 1988}

Hohlfelder, R. L., The 1984 Explorations of the Ancient Harbors of Caesarea Maritima Maritima, Bulletin of the American Schools of Oriental Research 25, 1-12.

HOHLFEDER/OLESON/RABAN/VANN 1983

Hohlfelder, R. L./Oleson, J. P./Raban, A./Vann, R. L., Sebastos: Herod's Harbor at Caesarea Maritima Maritima, Biblical Archaeologist 46, 133-43.

HOLUM 2004

Holum, K. G., Caesarea Maritima's Temple Hill: The Archaeology of Sacred Space in an Ancient Mediterranean City, Near Eastern Archaeology 67, 184-99.

HOLUM 1999

Holum, K. G., The Temple Platform: Progress Report on the Excavations in Caesarea Papers, Holum, K. G./Raban, A./ Patrich, J. (eds.) Journal of Roman Archaeology 2, 12-34.

JEFFERS 1999

Jeffers, J. S., The Greco-Roman World of the New Testament Era: Exploring the Background of Early Christianity (New York: InterVarsity Press).

\section{KLEINER 2014}

Kleiner, D.E.E., Roman Architecture: A Visual Guide (New Haven, London: Yale University Press).

\section{LEVINE 1975}

Levine, L.I., Caesarea Maritima Under Roman Rule (Leiden: Brill).

\section{KOKKINOS 1998}

Kokkinos, N., The Herodian Dynasty (Sheffield: Sheffield Academic Press).

MACDONALD 1986

MacDonald, W. L., The Architecture of the Roman Empire: An Urban Appraisal (New Haven: Yale University Press).

\section{MACMULLEN 1981}

MacMullen, R., Paganism in the Roman Empire (New Haven: Yale University Press).

\section{MAGNESS 2012}

Magness, J., The Archaeology of the Holy Land: From the Destruction of Solomon's Temple to the Muslim Conquest (Cambridge: Cambridge University Press).

\section{MAGNESS 2001}

Magness, J., The Cults of Isis and Kore at Samaria-Sebaste in the Hellenistic and Roman Periods, The Harvard Theological Review 94, 157-77.

\section{MARSHAK 2015}

Marshak, A. K., The Many Faces of Herod The Great (Grand Rapids: Eerdmans).

\section{MCCANE 2008}

McCane, B. R., Simply Irresistible: Augustus, Herod and the Empire, Journal of Biblical Literature 127, 725-35.

\section{MILNE 1913}

Milne, J. G., A History of Egypt Under Roman Rule (London: Methuen \& Co).

\section{MUELLER 2008}

Mueller, T., The Holy Land's Visionary Builder, National Geographic 214, 34-59.

NEGEV 1976

Negev, A., Samaria later Sebaste Jordan/Israel, The Princeton Encyclopedia of Classical Sites. http://www.perseus.tufts.edu/ hopper/text?doc=Perseus\%3Atext\%3A1999.04.0006\%3 Aalphabetic+letter\%3 DS\%3 Aentry+group $\% 3 \mathrm{D} 3 \% 3$ Aentry\%3Dsamaria. Accessed 16 May 2016.

NELSON 2015

Nelson, M. C., The Temple Complex at Horvat Omrit (Leiden: Brill).

NETZER 2009 
Netzer, E., The Architecture of Herod the Great Builder (Grand Rapids: Baker Academic).

\section{OLAMI/PELEG 1977}

Olami, Y./Peleg, Y., The Water Supply System of Caesarea Maritima Maritima, Israel Exploration Journal 27, 127-137.

\section{PELEG-BARKAT 2014}

Peleg-Barkat, O., Fit for a King: Architectural Décor in Judaea and Herod as Trendsetter, American Schools of Oriental Research 371, 141-61.

PEROWNE 2015

Perowne, S. H., Herod: King of Judea. Encyclopedia Brittanica. http://www.britannica.com/biography/Herodking-of-Judaea. Accessed 16 May 2016.

RABAN/HOLUM/PATRICH 1999

Raban, A./Holum, K.G./Patrich, J., The Underwater Excavations 1993-1994, Journal of Roman Archaeology 2, 158-168.

REGEV 2012

Regev, E., Inside Herod's Courts: Social Relations and Royal Ideology in the Herodian Palaces, Journal for the Study of Judaism 43, 180-214.

REIFENBERG 1951

Reifenberg, A., Caesarea Maritima: A Study in the Decline of a Town, Israel Exploration Journal 1, 20-32.

\section{REISNER/FISHER/LYON 1924}

Resner, G. A./Fisher, C. S./Lyon, D. G., Harvard Excvations at Samaria, 1908-1910 (Cambridge: Harvard University Press).

\section{RICHARDSON 2004}

Richardson, P., Building Jewish in the Roman East (Waco: Baylor University Press).

RICHARDSON 1996

Richardson, P., Herod: King of the Jews and Friend of the Romans (Columbia: University of South Carolina Press).

ROCCO 2008

Rocca, S., Herod's Judaea: A Mediterranean State in the Classic World (Eugene: Wipf and Stock Publishers).

SCHURER 1886

Schürer, E.,Geschichte des jüdischen Volkes im Zeitalter Jesu Christi (Leipzig: J.C. Hinrichs).

\section{SMITH 1987}

Smith, R. R., The Emperors Reliefs from the Sebasteion at Aphrodisias, The Journal of Roman Studies 77, 88-138.

\section{STAMPER 2005}

Stamper, J. W., The Architecture of Roman Temples: The Republic to the Middle Empire (Cambridge: Cambridge University Press).

\section{STRONG 1960}

Strong, D.E., Some Early Examples of the Composite TAKACS 1995 Capital, Journal of Roman Studies 50, 119-28.

Takacs, S. A., Isis and Sarapis in the Roman World (Leiden: Brill).

TOHER 2001

Toher, M., Nicolaus and Herod in the Antiquitates Judaicae, Harvard Studies in Classical Philology 101, 427-47.

WALLACE-HADRILL 2005

Wallace-Hadrill, A., Mutatas Formas: The Augustan Transformation of Roman Knowledge. Galinsky, K. (ed.) in the Cambridge Companion to the Age of Augustus (New York: Cambridge University Press).

\section{VILNAY 1928}

Vilnay, Z., A New Inscription from the Neighbourhood of Caesarea Maritima, Quarter Stat. Palestine Explorer Fund 60, 45-47.

WEISS 2014

Weiss, Z., Buildings for Mass Entertainment: Tradition and Innovation in Herodian Construction, Near Eastern Archaeology 2, 98-107.

\section{YEGUL 2012}

Yegul, F. K., Roman Decorative Arts: Roman Architecture in vol. 3. Silberman, N.A./Bauer, A.A./Holtorf, C/DiazAndreu, M./Waterton, E. (eds.), The Oxford Companion to Archaeology Second Edition (New York: Oxford University Press).

\section{ZANKER 2007}

Zanker, P., The Power of Images in the Age of Augustus (Ann Arbor: The University of Michigan Press). 